\title{
Using eastern gamagrass to construct diets that limit intake and caloric density for dairy replacement heifers ${ }^{1}$
}

\author{
W. K. Coblentz, ${ }^{2}$ P. C. Hoffman, $†$ N. M. Esser, $\ddagger$ and M. G. Bertram $\ddagger$ \\ *US Department of Agriculture-Agricultural Research Service (USDA-ARS), US Dairy Forage Research Center, Marshfield, WI 54449 \\ †Department of Dairy Science, University of Wisconsin, Madison 53706 \\ fUniversity of Wisconsin, Marshfield Agricultural Research Station, Marshfield 54449
}

\section{ABSTRACT}

Previous research has shown that eastern gamagrass (EGG; Tripsacum dactyloides L.) will survive winter climatic conditions common throughout central Wisconsin, and will produce yields of dry matter (DM) ranging approximately from 7,000 to $10,000 \mathrm{~kg} / \mathrm{ha}$ annually when managed with a 1 -cut harvest system. The objective of this research was to determine whether the fibrous nature of this perennial warm-season grass could be effective in reducing the caloric density and DMI of corn silage/alfalfa haylage diets for replacement dairy heifers. A total of 120 Holstein dairy heifers were blocked by body weight (heavy, $424 \pm 15.9 \mathrm{~kg}$; medium, $369 \pm 11.8 \mathrm{~kg}$; light, $324 \pm 22.4 \mathrm{~kg}$ ), and then assigned to 15 individual pens containing 8 heifers each. Eastern gamagrass forage was harvested, ensiled, and subsequently incorporated into blended corn silage/ alfalfa haylage diets at rates of $0,9.1,18.3$, or $27.4 \%$ of the total dietary DM (EGG0, EGG9, EGG18, and EGG27, respectively). These diets were offered during a 105-d evaluation period for ad libitum intake; however, the EGG0 diet also was offered on a limit-fed basis (LF), which was set at $85 \%$ of the voluntary intake of EGG0. Serial additions of EGG increased concentrations of neutral detergent fiber in blended diets from 39.6 (EGG0) to 48.7\% (EGG27), and simultaneously reduced corresponding estimates of total digestible nutrients (TDN) from 68.2 to $61.3 \%$, and net energy for gain from 1.07 to $0.83 \mathrm{Mcal} / \mathrm{kg}$. Dry matter intakes for all diets offered ad libitum were greater than observed for LF (9.06 vs. $8.07 \mathrm{~kg} / \mathrm{d}$ ); however, DM intakes for diets containing EGG were reduced relative to EGG0 (9.40 vs. $8.94 \mathrm{~kg} / \mathrm{d})$. Similarly, intakes of TDN were greater for diets offered for ad libitum intake than for

Received May 2, 2012.

Accepted June 22, 2012.

${ }^{1}$ Mention of trade names or commercial products in this article is solely for the purpose of providing specific information, and does not imply either recommendation or endorsement by the US Department of Agriculture.

${ }^{2}$ Corresponding author: wayne.coblentz@ars.usda.gov
LF (5.84 vs. $5.50 \mathrm{~kg} / \mathrm{d})$; however, inclusion of EGG reduced TDN intakes relative to EGG0 (6.41 vs. 5.65 $\mathrm{kg} / \mathrm{d}$ ). This reduction was explained by both linear and quadratic effects of the inclusion rate of EGG in the diet. Over the 105-d trial, total weight gains ranged from $89 \mathrm{~kg}(0.85 \mathrm{~kg} / \mathrm{d})$ for heifers offered EGG27 up to $114 \mathrm{~kg}(1.09 \mathrm{~kg} / \mathrm{d})$ for those offered EGG0. Performance was similar between heifers offered EGG27 and $\mathrm{LF}$ diets (0.85 vs. $0.88 \mathrm{~kg} / \mathrm{d}$ ). Eastern gamagrass haylage proved to be a completely nonsortable additive within corn silage/alfalfa haylage diets. It also was effective in limiting the caloric density and DM intake of these diets, as well as undesirable weight gains by dairy heifers.

Key words: eastern gamagrass, dairy heifer, dry matter intake, energy

\section{INTRODUCTION}

Ideally, dairy replacement management programs seek to rear heifers at a low economic and environmental cost without compromising their future performance as lactating cows (Hoffman et al., 2007). Generally, replacement dairy heifers are offered forage-based diets, but diets comprised of high-quality forages, especially those with significant proportions of corn (Zea mays L.) silage, can pose numerous challenges for heifer-rearing operations. Specifically, these problems arise because corn silage is energy dense, and often exceeds the energy requirements for dairy heifers, thereby resulting in excessive weight gains and overconditioning. Previous work has shown that elevated prepubertal ADG has a negative effect on mammary development (Sejrsen et al., 1982), and first-lactation milk yield (Van Amburgh et al., 1998; Lammers et al., 1999; Radcliff et al., 2000). In addition, Hoffman et al. (1996) demonstrated that excessive postpubertal growth coupled with early calving also resulted in depressed first-lactation performance. Although alfalfa (Medicago sativa L.) haylage complements corn silage quite well from the perspective of meeting protein requirements for dairy heifers, its energy density is often too great to sufficiently offset 
the energy-dense characteristics of corn silage for replacement heifers. Generally, 2 strategies have been evaluated to limit caloric intake by replacement heifers. These include (1) dilution of the diet with low-energy forages, such as straw (Greter et al., 2008) or (2) limit feeding (Hoffman et al., 2007; Zanton and Heinrichs, 2007; Zanton and Heinrichs, 2008; Kruse et al., 2010). However, cereal-grain straws are frequently expensive purchased inputs, recently reaching prices as high as $\$ 210 / \mathrm{Mg}$ throughout central Wisconsin. Furthermore, the inclusion of chopped straws within blended diets is notorious for encouraging undesirable sorting behaviors by heifers, especially those that discriminate against long particles (Greter et al., 2008). The concept of limit feeding has gained in popularity during recent years; however, competition for feed among heifers, primarily as a result of inadequate bunk space, increases day-today variations in feeding behavior (DeVries and von Keyserlingk, 2009), as well as within-pen variability with respect to daily weight gains (Longenbach et al., 1999). Therefore, a nonsortable, low-energy dietary additive that permits ad libitum intake of diets containing corn silage without concomitant overconditioning would be a valuable tool for improving feeding management strategies for dairy heifers.

Eastern gamagrass (EGG; Tripsacum dactyloides L.) is a perennial bunch-type grass that is a distant relative of corn (Bates et al., 1981), and possesses the C4 photosynthetic pathway (Waller and Lewis, 1979). Generally, it is noted for adaptability to moist soil conditions (Stubbendieck et al., 1982), as well as high production potential (Brejda et al., 1996; Brejda et al., 1997; Mashingo et al., 2008), responsiveness to $\mathrm{N}$ fertilization (Brejda et al., 1996), and suitability with regard to conservation as silage (Brejda et al., 1994; Coblentz et al., 1999; Eun et al., 2003). Recently, research conducted in central Wisconsin has verified that this perennial warm-season grass can survive winter climatic conditions throughout the region, and will produce yields of DM ranging generally from 7,000 to $10,000 \mathrm{~kg} / \mathrm{ha}$ by mid-August using a 1-cut harvest system (Coblentz et al., 2010b). Furthermore, concentrations of NDF in EGG forages harvested during this time period ranged from 74.6 to $80.1 \%$ (Coblentz et al., 2010a). However, estimation of TDN by the summative equation (NRC, 2001) for these forages was complicated by discrepancies in determining totally digestible fiber. In part, this was caused by the relatively limited lignification of cell walls occurring by mid-August (3.75 to 4.60\%), likely in response to the cool growing conditions (Coblentz et al., 2010a). On this basis, the potential of EGG for diluting the energy density of heifer diets containing high-quality forages remains unclear. However, intensive evaluation of typical dairy-heifer diets offered in confinement (Hoffman et al., 2008) has indicated that dairy heifers consume approximately $1.0 \%$ of their BW daily as NDF. In theory, caloric intake could be reduced on this basis by simply incorporating high-NDF forages within dairy-heifer diets, thereby limiting total DMI. Our objectives were to determine if serial additions of EGG to corn silage/alfalfa haylage diets would be effective at reducing daily weight gains by (1) diluting the energy density of the diet, (2) reducing DMI, or (3) through a combination of both mechanisms.

\section{MATERIALS AND METHODS}

\section{Establishment, Harvest, and Storage of EGG}

During May 2009, a 2.4-ha field site at the University of Wisconsin Marshfield Agricultural Research Station, located near Stratford $\left(44^{\circ} 7^{\prime} \mathrm{N}, 90^{\circ} 1^{\prime} \mathrm{W}\right)$, was clean-tilled in preparation for establishment of EGG. The soil type at this location was a Withee silt loam (fine-loamy, mixed, frigid, Aeric Glossaqualfs), and the previous crop on the site was corn that was harvested as grain during the previous fall. On May 6, 2009, Pete EGG was planted with a John Deere 4-row planter (model 7000; Deere and Co., Moline, IL) at approximately 138,600 seeds/ha (9 kg/ha). Eastern gamagrass seeds were pretreated to facilitate breaking dormancy, thereby allowing quick germination (Germtec II; Gamagrass Seed Co., Falls City, NE). On April 28, 2010, residual growth remaining from the establishment year was clipped to a $10-\mathrm{cm}$ stubble height with a rotary mower, and then fertilized with urea (46-0-0) at a rate of $80 \mathrm{~kg}$ of N/ha. Subsequently, the entire stand was mowed to a 15 -cm stubble height, precision-chopped, and ensiled in a plastic silo bag on September 9, 2010, yielding approximately $6,000 \mathrm{~kg}$ of DM/ha. The corn silage and alfalfa haylage used in this study also were ensiled in plastic silo bags, and were obtained from production-scale fields at the Marshfield Agricultural Research Station (Marshfield, WI).

\section{Animals, Housing, and Diets}

All animal handling procedures for this experiment were approved by the Research Animal Resources Committee (RARC) of the University of WisconsinMadison (Protocol \#A01458). One hundred twenty Holstein heifers were segregated (40 heifers/block) on the basis of initial BW (HVY, $424 \pm 15.9 \mathrm{~kg}$; MED, $369 \pm 11.8 \mathrm{~kg} ; \mathbf{L T}, 324 \pm 22.4 \mathrm{~kg}$ ), and then assigned randomly in groups of 8 heifers to 1 of 15 identical research pens ( 5 pens/block). Each pen was equipped with continuous access to fresh water, 8 sand-bedded freestalls, an automatically controlled mechanical alley- 
scraping system, and 8 locking headgates positioned adjacent to a drive-by feed alley. Headlocks were set to allow free access and departure from the feed bunk at all times. All feedstuffs were dispensed as a TMR once daily at approximately $0900 \mathrm{~h}$; subsequently, blended diets were pushed back within easy reach of the heifers at least twice before orts were gathered before feeding $(0900 \mathrm{~h})$ the following day.

Each of the 15 research pens was assigned to 1 of 5 isonitrogenous diets (Table 1). Furthermore, each of the 5 diets was assigned only once within each block of 5 pens; as a result, all diets were represented within each block, and no block contained duplicate pen assignments of any diet. A negative control diet comprised a 47:53 blend (DM basis) of alfalfa haylage and corn silage (EGG0), and was intentionally formulated to exceed the energy requirements of heifers within this BW range (NRC, 2001). The negative control diet was formulated to realistically depict the problematic nature of heifer diets containing excess proportions of corn silage, and correspondingly excessive energy. The EGG0 diet was then altered with serial additions of EGG haylage, thereby creating diets comprising 9.1, 18.3, or 27.4\% EGG on a DM basis (EGG9, EGG18, or EGG27, respectively). Generally, EGG haylage was substituted directly for corn silage during diet formulation; however, EGG contained slightly greater concentrations of CP than corn silage (8.2 vs. $6.7 \%$; Table 1 ), and some minor dietary adjustments were necessary to maintain isonitrogeneity. A positive control diet also was evaluated in the study; this diet (LF) was formulated exactly as EGG0, but was offered on a limit-fed basis at $85 \%$ of the daily intake of EGG0 (Kruse et al., 2010) to more closely meet the caloric and protein requirements (NRC, 2001) for dairy heifers in this BW range gaining $0.85 \mathrm{~kg} / \mathrm{d}$. The 4 diets offered for ad libitum intakes (EGG0, EGG9, EGG18, and EGG27) were managed to a defined bunk score of 2 , where 0 $=$ no feed particles remaining; $1=$ only scattered feed particles remaining; $2=$ numerous particles remaining, but the concrete floor still easily visible; and $3=$ feed particles completely covering the concrete bunk floor (Hoffman et al., 2008). Bunks were scored each morning, and the amount of TMR was adjusted daily on this basis to maintain the preestablished bunk score of 2 ; normally, a bunk score of 0 triggered an approximate $5 \%$ increase in the daily diet allocation, calculated on an as-is basis. Generally, the daily diet allocation for $\mathrm{LF}$ heifers was consumed within about $8 \mathrm{~h}$, and a final daily bunk score of 0 was recorded for these pens with few exceptions over the 105-d feeding trial.

Samples of each diet were obtained daily, frozen $\left(-20^{\circ} \mathrm{C}\right)$, and composited by week for analysis. Orts were sampled similarly; each morning, orts were swept from the bunk of each pen and placed in a large (tared) plastic tub. The weight of refusals collected each morning was then recorded for each pen. Orts from each pen were subsampled daily, frozen $\left(-20^{\circ} \mathrm{C}\right)$, and then composited by week. A 400-g subsample of the weekly orts composite from each pen was placed into a paper bag and dried to constant weight under forced air at $55^{\circ} \mathrm{C}$ to determine the concentration of $\mathrm{DM}$ within the orts. Using the bunk-scoring system described previously, the daily amount of orts recovered for each pen was generally very small $(<0.5 \mathrm{~kg}$ of $\mathrm{DM} /$ pen per day); because this amount of refusal comprised $<1 \%$ of the total DM offered to each pen daily, the chemical composition of the orts was not analyzed, and it was assumed to be the same as the blended diets for all subsequent calculations.

\section{Laboratory Analysis of Diets}

Weekly diet samples were dried to constant weight under forced air at $55^{\circ} \mathrm{C}$, and then ground through a 1-mm screen in a Thomas model 4 Wiley mill (Thomas Scientific, Swedesboro, NJ). Samples then were analyzed by the University of Wisconsin Soil and Forage Laboratory (Marshfield, WI) for (1) CP content by a macro-Kjeldahl procedure (AOAC International, 1998; method 988.05); (2) ash content by combustion in a muffle furnace at $500^{\circ} \mathrm{C}$ for $6 \mathrm{~h}$; (3) starch content (model 2700D; Yellow Springs Instrument Co., Yellow Springs, OH); (4) fat content (AOAC, 1990; method 920.29); (5) Ca, K, and $\mathrm{Mg}$ concentrations by atomic absorption spectroscopy; and (6) P content by colorimetric methodology (Schulte et al., 1987).

Fiber composition was quantified by sequential determination of NDF, ADF, hemicellulose, and ADL by the methods of Goering and Van Soest (1970). The NDF solution contained heat-stable amylase, but sodium sulfite was omitted. Independently, additional NDF and ADF residues were generated similarly, following direct digestion in either neutral- or acid-detergent solutions, respectively; residues were then analyzed for residual $\mathrm{CP}$ (neutral detergent-insoluble $\mathrm{CP}$ and acid detergent-insoluble $\mathrm{CP}$, respectively) by a rapid combustion procedure (AOAC International, 1998, method 990.03; Elementar Americas Inc., Mt. Laurel, NJ). For determinations of neutral detergent-insoluble $\mathrm{CP}$, the NDF solution contained no sodium sulfite to limit excessive removal of $\mathrm{CP}$ associated with the forage fiber matrix (Van Soest et al., 1991).

Procedures and apparatuses for determining 48-h NDF digestibility (NDFD) were similar to those described previously (Coblentz and Hoffman, 2009; Kruse et al., 2010); briefly, they consisted of incubating $0.5-\mathrm{g}$ samples in $125-\mathrm{mL}$ Erlenmeyer flasks containing rumen 
Table 1. Ingredient composition of experimental diets with or without eastern gamagrass (EGG) haylage, and nutrient composition of blended diets and individual dietary components

\begin{tabular}{|c|c|c|c|c|c|c|c|c|}
\hline \multirow[b]{2}{*}{ Item } & \multicolumn{5}{|c|}{ Blended $\operatorname{diet}^{1,2}$} & \multicolumn{3}{|c|}{ Dietary component } \\
\hline & EGG0 & EGG9 & EGG18 & EGG27 & $\mathrm{LF}$ & $\begin{array}{c}\text { Alfalfa } \\
\text { haylage }\end{array}$ & $\begin{array}{l}\text { Corn } \\
\text { silage }\end{array}$ & $\begin{array}{c}\text { EGG } \\
\text { haylage }\end{array}$ \\
\hline \multicolumn{9}{|l|}{ Ingredient } \\
\hline Alfalfa haylage & 46.5 & 45.8 & 44.6 & 43.4 & 46.5 & - & - & - \\
\hline Corn silage & 52.9 & 44.4 & 36.5 & 28.5 & 52.9 & - & - & - \\
\hline EGG haylage & 0.0 & 9.1 & 18.3 & 27.4 & 0.0 & - & - & - \\
\hline $\mathrm{DM}$ & 40.1 & 39.9 & 40.5 & 40.6 & 40.1 & 44.2 & 38.1 & 39.6 \\
\hline $\mathrm{CP}$ & 12.9 & 13.0 & 13.1 & 12.9 & 12.9 & 20.2 & 6.7 & 8.2 \\
\hline $\mathrm{NDICP}^{4}$ & 2.9 & 2.9 & 3.0 & 3.3 & 2.9 & 3.9 & 1.3 & 3.1 \\
\hline $\mathrm{ADICP}^{5}$ & 1.1 & 1.1 & 1.2 & 1.4 & 1.1 & 2.3 & 0.6 & 1.4 \\
\hline $\mathrm{NDF}^{6}$ & 39.6 & 43.0 & 45.6 & 48.7 & 39.6 & 41.1 & 38.0 & 69.7 \\
\hline $\mathrm{NDFD},{ }^{7} \%$ of NDF & 53.2 & 51.5 & 50.1 & 49.0 & 53.2 & 45.9 & 55.2 & 48.5 \\
\hline $\mathrm{ADF}^{6}$ & 26.9 & 28.8 & 30.4 & 31.5 & 26.9 & 33.0 & 21.7 & 39.2 \\
\hline $\mathrm{P}$ & 0.25 & 0.26 & 0.26 & 0.28 & 0.25 & 0.31 & 0.23 & 0.20 \\
\hline $\mathrm{Ca}$ & 0.72 & 0.72 & 0.74 & 0.69 & 0.72 & 0.98 & 0.19 & 0.23 \\
\hline $\mathrm{K}$ & 1.66 & 1.72 & 1.80 & 1.76 & 1.66 & 2.69 & 0.85 & 1.45 \\
\hline $\mathrm{Mg}$ & 0.20 & 0.21 & 0.22 & 0.21 & 0.20 & 0.26 & 0.11 & 0.21 \\
\hline \multicolumn{9}{|l|}{ Energy estimate $^{8}$} \\
\hline TDN & 68.2 & 65.3 & 63.2 & 61.3 & 68.2 & 60.7 & 72.4 & 52.0 \\
\hline ME, Mcal/kg & 2.59 & 2.46 & 2.36 & 2.28 & 2.59 & 2.26 & 2.77 & 1.87 \\
\hline $\mathrm{NE}_{\mathrm{G}}, \mathrm{Mcal} / \mathrm{kg}$ & 1.07 & 0.97 & 0.90 & 0.83 & 1.07 & 0.81 & 1.21 & 0.47 \\
\hline $\mathrm{NE}_{\mathrm{M}}, \mathrm{Mcal} / \mathrm{kg}$ & 1.68 & 1.57 & 1.49 & 1.41 & 1.68 & 1.39 & 1.84 & 1.02 \\
\hline
\end{tabular}

${ }^{1}$ EGG0 = alfalfa haylage/corn silage diet containing no EGG offered for ad libitum intake; EGG9 = alfalfa haylage/corn silage diet containing 9.1\% EGG offered for ad libitum intake; EGG18 = alfalfa haylage/corn silage diet containing 18.3\% EGG offered for ad libitum intake; EGG27 = alfalfa haylage/corn silage diet containing 27.4\% EGG offered for ad libitum intake; LF = EGG0 diet offered at 85\% of DMI for EGG0.

${ }^{2}$ All ingredients or nutrients are expressed on a percentage of DM basis unless otherwise noted.

${ }^{3}$ Mineral package contained $72.1 \%$ calcium carbonate, $16.5 \%$ salt, $3.35 \%$ sulfur, $2.95 \%$ selenium $1600,1.50 \%$ vitamin A, $0.75 \%$ mineral oil, $0.71 \%$ copper sulfate, $0.69 \%$ vitamin E (50\%), $0.64 \%$ zinc sulfate, $0.51 \%$ vitamin $\mathrm{D}, 0.09 \%$ iodine mix, $0.005 \%$ magnesium sulfate, $0.005 \%$ cobalt carbonate, $0.005 \%$ manganese oxide $(60 \%)$, and $0.26 \%$ thiamine. The mineral package was blended into the total diet and delivered as a TMR.

${ }^{4}$ Neutral detergent-insoluble CP

${ }^{5}$ Acid detergent-insoluble CP

${ }^{6}$ Neutral detergent fiber, ADF, and ADL were determined sequentially, without sulfite added to the NDF solution.

${ }^{7}$ Neutral detergent fiber digestibility (NDFD) determined following a 48-h digestion in buffered rumen fluid.

${ }^{8}$ Energy calculations based on NRC (2001).

fluid, buffer media, and macro- and micro-mineral solutions (Goering and Van Soest, 1970). Rumen fluid was collected from a single nonlactating Holstein dairy cow fitted with a ruminal cannula and offered a forage diet composed of mostly alfalfa hay. Incubation flasks were purged continuously with $\mathrm{CO}_{2}$ and maintained in a temperature-controlled water bath at $39^{\circ} \mathrm{C}$ during an incubation period lasting $48 \mathrm{~h}$. Digestion was terminated with neutral detergent that included both heat-stable $\alpha$-amylase and sodium sulfite (Goering and Van Soest, 1970; Mertens, 1992), and 48-h NDFD was calculated based on an independent initial assessment of NDF for each sample that was obtained with both additives included in the neutral-detergent solution. Calculations of TDN for each diet were made via the summative approach (NRC, 2001), with 48-h NDFD serving as a digestibility coefficient for NDF to estimate truly digestible fiber. Other energy calculations $\left(\mathrm{ME}, \mathrm{NE}_{\mathrm{G}}\right.$, and $\mathrm{NE}_{\mathrm{M}}$ ) were made as described by $\mathrm{NRC}$ (2001).

\section{Body Measurements}

Initial and final heifer BW were based on the mean BW of each heifer, determined on 3 consecutive mornings immediately before feed was delivered to each pen. Heifers were weighed using a cattle chute (Real-Tuff Inc., Clearbrook, MN) equipped with an electronic scale (Tru-Test Inc., Mineral Wells, TX). On 1 of the 3 consecutive initial and final weigh days, frame measure- 
ments were taken on each heifer that included heart girth, body length, hip height, and hip width (Esser et al., 2009). At the same time, BCS was assessed by a trained evaluator on a scale of 1 to 5 , where $1=$ emaciated and $5=$ obese (Wildman et al., 1982). For BCS, increments of 0.5 units were applied to best describe the body condition of each heifer.

\section{In Situ Evaluation of Forages}

Within the MED heifer-weight block only, 1 heifer assigned to each of the 5 diets was fitted with a ruminal cannula. During the 105-d trial, these heifers were rotated through the 5 pens within the MED block in a $5 \times 5$ Latin square concept composed of five $21-d$ experimental periods. From a production-measurement standpoint, the cannulated heifers contributed to the gross nutrient intakes of each pen, but their growth and performance measurements were omitted from all pen means within the MED block. On d 1 of each experimental period, additional samples $(\sim 1 \mathrm{~kg})$ were obtained from the blended diets, as well as the individual ensiled forages (corn silage, alfalfa haylage, and EGG haylage). These forages were dried to constant weight under forced air at $55^{\circ} \mathrm{C}$, and then ground through a Wiley mill equipped with a $2-\mathrm{mm}$ screen in preparation for in situ analysis. Cannulated heifers were adapted to their respective diets from d 1 through 12 of each experimental period. During this time, 5 -g samples of dried, ground diets and individual silages were sealed within $10 \times 20$-cm Dacron bags $(50 \pm 10-\mu \mathrm{m}$ pore size; Ankom Technology Corp., Macedon, NY), and then grouped within $35 \times 50-\mathrm{cm}$ mesh bags on the basis of withdrawal time. Each larger mesh bag contained 4 Dacron bags, 3 of which were assigned to the individual silages comprising the diets, whereas the remaining Dacron bag contained the blended diet consumed by each heifer during that experimental period. At $0730 \mathrm{~h}$ on d 13 , all bags were incubated in tepid water $\left(39^{\circ} \mathrm{C}\right)$ for $20 \mathrm{~min}$, immediately inserted ( $\sim 0800 \mathrm{~h})$ simultaneously into the ventral rumen, and then incubated for $3,6,9$, $12,24,36,48,72$, or $96 \mathrm{~h}$. After removal from the rumen, samples were rinsed immediately in a top-loading washing machine using 10 cold-water rinse cycles, where each rinse cycle consisted of 1 min of agitation coupled with a 2-min spin cycle (Coblentz et al., 1997; Vanzant et al., 1998). In addition, a 0-h incubation time for each individual silage or blended diet was created with an identical tepid-water soak, followed by machine rinsing, but without ruminal incubation. After machine rinsing procedures were completed, residues were dried under forced air at $55^{\circ} \mathrm{C}$, equilibrated with the atmosphere in the laboratory (Vanzant et al., 1996), and then weighed to determine residual DM.
To determine disappearance kinetics of NDF, $0.5-\mathrm{g}$ subsamples of the air-equilibrated residues from each Dacron bag were digested in NDF using batch procedures outlined by Ankom Technology Corp. for an ANKOM200 fiber analyzer. Heat-stable $\alpha$-amylase was included in the neutral-detergent solution, but sodium sulfite was omitted. The percentage of DM or NDF remaining at each incubation time was fitted to the nonlinear regression model of Mertens and Loften (1980) using PROC NLIN of SAS (SAS Institute, 2002). Dry matter or NDF was partitioned into 3 fractions (A, $\mathrm{B}$, and $\mathrm{C}$ ) based on relative susceptibility to ruminal disappearance, where fraction A disappeared at a rate too fast to measure, fraction $\mathrm{B}$ disappeared at a measurable rate, and fraction $\mathrm{C}$ was unavailable in the rumen. Using this approach, fractions B and C, as well as discrete lag time and disappearance rate $\left(\mathbf{K}_{\mathbf{d}}\right)$ were determined directly from the regression model. Fraction A was calculated by difference as $100 \%-(B+C)$. Effective ruminal disappearance of DM and NDF were calculated as $\mathrm{A}+\left\{\mathrm{B} \times\left[\mathrm{K}_{\mathrm{d}} /\left(\mathrm{K}_{\mathrm{d}}+\mathrm{K}_{\mathrm{p}}\right)\right]\right\}$ (Ørskov and McDonald, 1979), where $\mathrm{K}_{\mathrm{p}}$ was an arbitrarily assigned ruminal passage rate of $0.040 / \mathrm{h}$.

\section{Rumen Measurements}

Following in situ analysis, cannulated heifers from the MED block were allowed $2 \mathrm{~d}$ of recovery time, and then rumen contents were sampled manually from various positions within the rumen beginning at $0800 \mathrm{~h}$ on d 20 of each experimental period, and continuing at 4-h intervals for 2 consecutive days. Approximately 3 $\mathrm{L}$ of whole rumen contents was removed at each sampling interval, mixed thoroughly in a bucket, and then squeezed through 4 layers of cheesecloth. Rumen fluid was immediately analyzed for $\mathrm{pH}$ (Accumet model AP110; Fisher Scientific, Pittsburgh, PA), and then an aliquot of $16 \mathrm{~mL}$ of strained rumen fluid was added to $4 \mathrm{~mL}$ of $25 \%$ (wt/vol) metaphosphoric acid. Acidified rumen fluid was then sealed in plastic vials, and frozen $\left(-20^{\circ} \mathrm{C}\right)$ pending later quantification of VFA by gas chromatography (model GC-2010; Shimadzu Corp., Kyoto, Japan).

\section{Statistics}

Nutrient intakes and heifer production data were analyzed with PROC GLM procedures of SAS (SAS Institute, 2002) as a randomized complete block design with 3 replications (blocks: LT, MED, and HVY). For these measurements, the pen served as the experimental unit (St-Pierre, 2007), thereby permitting 14 total degrees of freedom for the statistical analysis. Orthogonal contrasts were used to separate the effects 
of dietary treatment. These included (1) all ad-libitum diets (EGG0, EGG9, EGG18, and EGG27) versus LF, (2) EGG0 versus all diets containing EGG (EGG9, EGG18, and EGG27), (3) a linear effect of serial addition of EGG, and (4) a quadratic effect of serial addition of EGG. In situ degradation characteristics of DM and NDF were analyzed as a $5 \times 5$ Latin square design using PROC GLM procedures of SAS (SAS Institute, 2002); separation of treatment means was conducted by the orthogonal contrasts described previously for production data. Ruminal VFA data were averaged for each heifer across sampling times, and then analyzed as described for the in situ data. Ruminal $\mathrm{pH}$ data were subjected to polynomial regression techniques, with time expressed as hours from $0800 \mathrm{~h}$ as the independent variable (PROC REG; SAS Institute, 2002); this approach allowed the specific determination of minimum $\mathrm{pH}$ during the diurnal cycle, as well as the specific time that $\mathrm{pH}$ was most acidic.

\section{RESULTS}

\section{Diet Formulation}

Weekly analysis of the 5 experiment diets (Table 1 ) indicated that isonitrogeneity was maintained effectively across diets; concentrations of $\mathrm{CP}$ ranged narrowly from 12.9 to $13.1 \%$. Serial addition of EGG haylage to the EGG0 or LF diets was effective at increasing concentrations of NDF, ranging from 39.6 to $48.7 \%$ for EGG0 and EGG27, respectively. Based on in vitro analysis, the mean 48-h NDFD for EGG was $48.5 \%$ of NDF, which was intermediate between corn silage $(55.2 \%)$ and alfalfa haylage $(45.9 \%)$; as a result, the 48-h NDFD for the blended diets varied only modestly (49.0 to $53.2 \%$ of NDF) across diets. Concentrations of starch were reduced by $39 \%$ with the addition of EGG, ranging from $17.9 \%$ for EGG0 down to $10.9 \%$ for EGG27. Overall, the calculated energy density of the EGG0 diet (68.2\% TDN) was excessive (NRC, 2001) for heifers within this BW range, but the addition of 9.1, 18.3, and 27.4\% EGG reduced calculated TDN to $65.3,63.2$, and $61.3 \%$, respectively, thereby limiting TDN to levels consistent with the energy requirements for heifers of this size (NRC, 2001).

\section{Nutrient Intakes}

Intakes of DM (Table 2$)$ were greater $(P<0.001)$ for all diets offered for ad libitum intake compared with the LF control (9.06 vs. $8.07 \mathrm{~kg}$ ), but this only tended to differ on a percentage of BW basis (2.15 vs. $1.94 \%$ of $\mathrm{BW} ; P=0.060)$. Largely as a function of reduced DMI, most specific nutrient intakes also were reduced $(P \leq$
0.030) for heifers consuming the LF compared with ad libitum diets. Of these, 2 of the most important were reductions $(P<0.001)$ in respective intakes of NDF $(3.19$ vs. $4.00 \mathrm{~kg} / \mathrm{d})$ and TDN (5.50 vs. $5.84 \mathrm{~kg} / \mathrm{d})$. Across diets offered for ad libitum intake, the mean intake of NDF was $0.95 \%$ of $\mathrm{BW}$, which is consistent with predictions for heifers of this size and BW maintained in confinement (Hoffman et al., 2008). Starch intakes for heifers consuming the LF diet were greater (1.45 vs. $1.30 \mathrm{~kg} / \mathrm{d} ; P<0.001)$ than those observed for heifers offered ad libitum diets, but this observation largely resulted from substituting EGG for corn silage in the EGG9, EGG18, and EGG27 diets.

Collectively, DMI was reduced by $4.9 \%$ for any diet that included EGG, relative to EGG0 (8.94 vs. 9.40 $\mathrm{kg} / \mathrm{d} ; P=0.001$ ), and this response also was observed on a percentage of BW basis (2.13 vs. $2.21 \%$ of $\mathrm{BW}$; $P=0.050)$. Across diets offered for ad libitum intake, serial addition of EGG reduced DMI $(\mathrm{kg} / \mathrm{d})$ with both linear $(P=0.004)$ and quadratic $(P=0.019)$ effects of inclusion rate, but only a tendency for a linear effect $(P=0.059)$ was observed on a percentage of BW basis. Generally, the inclusion rate of EGG in the diet affected intakes of $\mathrm{OM}$, starch, fat, and $\mathrm{Ca}$ in patterns that paralleled those described for DMI. Conversely, intakes of fiber components (NDF, ADF, and hemicellulose), as well as digestible NDF, all were greater $(P \leq$ 0.006) for diets containing EGG compared with EGG0; in each case, a linear $(P<0.001)$ increase occurred with EGG inclusion rate, but quadratic effects $(P \leq 0.030)$ were observed only for digestible NDF and hemicellulose. The combined effects of reduced DMI, coupled with increased intakes of fiber components, elicited the desired effect on intakes of energy. Intakes of TDN were reduced in diets containing EGG compared with EGG0 (5.65 vs. $6.41 \mathrm{~kg} / \mathrm{d} ; P<0.001)$, and these reductions were explained by both linear $(P<0.001)$ and quadratic $(P=0.005)$ effects of EGG inclusion rate. The TDN intake of the EGG27 diet represented a $15 \%$ reduction compared with the EGG0 diet (5.48 vs. 6.41 $\mathrm{kg}$ of $\mathrm{TDN} / \mathrm{d}$ ), and was essentially identical to the daily TDN intake established by the positive-control LF diet $(5.50 \mathrm{~kg} / \mathrm{d})$.

\section{Heifer Growth and Performance}

Initial body measurements generally were similar across treatment groups, exhibiting no significant comparative contrasts for heart girth, body length, hip height, or hip width $(P \geq 0.083$; Table 3$)$. For initial BW and BCS, linear $(P \leq 0.041)$ effects of EGG inclusion rate were detected, but the overall ranges for these initial measurements were very narrow (368 to $376 \mathrm{~kg}$ and 3.0 to 3.2 BCS units, respectively). 
Table 2. Nutrient intakes for heifers consuming diets with or without eastern gamagrass haylage (EGG)

\begin{tabular}{|c|c|c|c|c|c|c|c|c|c|c|}
\hline Item & \multicolumn{5}{|c|}{ Blended $\operatorname{diet}^{1}$} & SEM & \multicolumn{4}{|c|}{ Contrast, ${ }^{2} P$-value } \\
\hline \multicolumn{11}{|l|}{ Nutrient intake } \\
\hline $\mathrm{DM}, \%$ of BW & 2.21 & 2.13 & 2.12 & 2.14 & 1.94 & 0.020 & 0.060 & 0.050 & 0.059 & 0.620 \\
\hline $\mathrm{CP}, \mathrm{kg} / \mathrm{d}$ & 1.21 & 1.16 & 1.17 & 1.15 & 1.04 & 0.011 & $<0.001$ & 0.003 & 0.008 & 0.133 \\
\hline $\mathrm{OM}, \mathrm{kg} / \mathrm{d}$ & 8.71 & 8.28 & 8.23 & 8.24 & 7.48 & 0.072 & $<0.001$ & 0.001 & 0.002 & 0.015 \\
\hline Digestible $\mathrm{NDF}^{3}{ }^{3} \mathrm{~kg} / \mathrm{d}$ & 1.98 & 1.98 & 2.04 & 2.13 & 1.70 & 0.017 & $<0.001$ & 0.006 & $<0.001$ & 0.030 \\
\hline $\mathrm{ADF}, \mathrm{kg} / \mathrm{d}$ & 2.53 & 2.58 & 2.71 & 2.81 & 2.17 & 0.023 & $<0.001$ & 0.001 & $<0.001$ & 0.278 \\
\hline Hemicellulose, $\mathrm{kg} / \mathrm{d}$ & 1.20 & 1.27 & 1.36 & 1.54 & 1.03 & 0.012 & $<0.001$ & $<0.001$ & $<0.001$ & 0.002 \\
\hline Starch, kg/d & 1.68 & 1.42 & 1.12 & 0.97 & 1.45 & 0.016 & $<0.001$ & $<0.001$ & $<0.001$ & 0.007 \\
\hline Fat, $\mathrm{kg} / \mathrm{d}$ & 0.22 & 0.19 & 0.19 & 0.19 & 0.19 & 0.002 & 0.011 & $<0.001$ & $<0.001$ & $<0.001$ \\
\hline Ash, kg/d & 0.69 & 0.67 & 0.70 & 0.69 & 0.59 & 0.006 & $<0.001$ & 0.431 & 0.335 & 0.135 \\
\hline TDN, kg/d & 6.41 & 5.85 & 5.63 & 5.48 & 5.50 & 0.053 & $<0.001$ & $<0.001$ & $<0.001$ & 0.005 \\
\hline ME, Mcal/d & 24.3 & 22.0 & 21.1 & 20.4 & 20.9 & 0.21 & 0.002 & $<0.001$ & $<0.001$ & 0.006 \\
\hline $\mathrm{NE}_{\mathrm{G}}, \mathrm{Mcal} / \mathrm{d}$ & 10.1 & 8.7 & 8.0 & 7.4 & 8.6 & 0.09 & 0.492 & $<0.001$ & $<0.001$ & 0.002 \\
\hline $\mathrm{NE}_{\mathrm{M}}, \mathrm{Mcal} / \mathrm{d}$ & 15.8 & 14.0 & 13.3 & 12.6 & 13.6 & 0.12 & 0.030 & $<0.001$ & $<0.001$ & 0.002 \\
\hline
\end{tabular}

${ }^{1}$ EGG0 = alfalfa haylage/corn silage diet containing no EGG offered for ad libitum intake; EGG9 = alfalfa haylage/corn silage diet containing 9.1\% EGG offered for ad libitum intake; EGG18 = alfalfa haylage/corn silage diet containing 18.3\% EGG offered for ad libitum intake; EGG27 $=$ alfalfa haylage/corn silage diet containing 27.4\% EGG offered for ad libitum intake; LF = EGG0 diet offered at $85 \%$ of DMI for EGG0.

${ }^{2}$ Contrasts: 1 = all ad libitum diets (EGG0, EGG9, EGG18, and EGG27) versus LF; 2 = EGG0 versus all diets containing EGG (EGG9, EGG18, and EGG27); 3 = linear effect of serial addition of EGG; and 4 = quadratic effect of serial addition of EGG.

${ }^{3}$ Values based on NDF intakes and a 48-h in vitro determination of NDF digestibility (NDFD).

${ }^{4}$ Energy calculations based on NRC (2001).

Final BW for heifers offered diets for ad libitum intake was greater than observed for LF heifers (475 vs. $464 \mathrm{~kg} ; P=0.012$ ), and heifers offered the EGG0 diet exhibited a greater final BW than heifers consuming diets containing EGG (484 vs. $471 \mathrm{~kg} ; P=0.004$ ). Serial addition of EGG to blended diets offered for ad libitum intake reduced final heifer BW linearly $(P=0.001)$ from $484 \mathrm{~kg}$ for EGG0 down to $465 \mathrm{~kg}$ for EGG27, which was almost identical to the final BW for LF heifers $(464 \mathrm{~kg})$. Similarly, final heart girth and BCS also were reduced linearly $(P \leq 0.022)$ by adding EGG to the diet; for BCS, this score ranged from 3.5 for EGG0 to 3.2 for EGG27, thereby providing qualitative confirmation of accelerated weight gains and increased adipose deposition when alfalfa/corn silage diets are offered for ad libitum intake. Total weight gains during the 105-d feeding trial were greater for heifers offered ad libitum diets compared with LF heifers (103 vs. 92 $\mathrm{kg} ; P=0.003)$, and were greater for EGG0 compared with diets containing EGG (114 vs. $99 \mathrm{~kg} ; P<0.001)$. Serial addition of EGG to heifer diets reduced total weight gains by approximately $1 \mathrm{~kg}$ for each percentage unit of EGG included within the diet; this effect was consistent across the entire range of ad libitum diets, exhibiting a strong linear $(P<0.001)$ effect, but without evidence of quadratic character $(P=0.448)$. Statistically similar responses were observed for ADG; inclusion of EGG within ad libitum diets reduced ADG by approximately $0.01 \mathrm{~kg} / \mathrm{d}$ for each percentage unit of EGG substituted into the diet. Changes in heart girth measurements during the 105-d trial were greater for heifers consuming the EGG0 diet compared with diets containing EGG (16.3 vs. $13.4 \mathrm{~cm} ; P=0.011)$, which was explained with linear $(P=0.001)$, but not quadratic $(P=0.250)$, effects of EGG inclusion rate. The ratio of feed:gain ( $\mathrm{kg}$ of feed $/ \mathrm{kg}$ of gain) was greater for diets containing EGG compared with EGG0 (9.6 vs. 8.6; $P=0.006)$, and increased linearly $(P<0.001)$ by $22.1 \%$ from 8.6 for the EGG0 diet to 10.5 for EGG27.

\section{In Situ Disappearance Kinetics}

Disappearance characteristics for individual dietary components (alfalfa haylage, corn silage, and EGG) varied little with basal diet; therefore, they are condensed and reported as overall means averaged across 
Table 3. Effects of diets with or without eastern gamagrass haylage (EGG) on body size and growth performance of Holstein replacement heifers

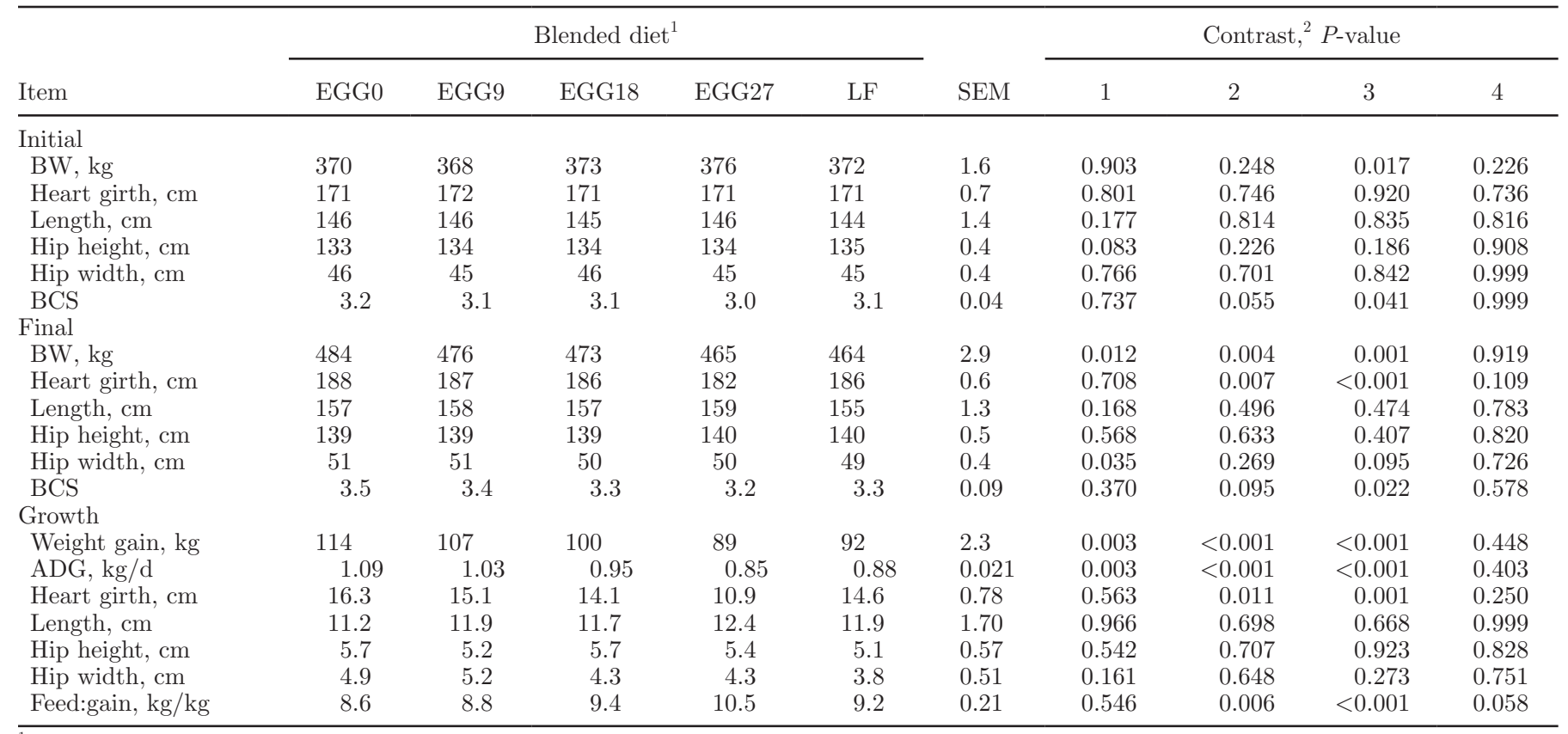

${ }^{1}$ EGG0 = alfalfa haylage/corn silage diet containing no EGG offered for ad libitum intake; EGG9 = alfalfa haylage/corn silage diet containing 9.1\% EGG offered for ad libitum intake; EGG18 = alfalfa haylage/corn silage diet containing 18.3\% EGG offered for ad libitum intake: EGG27 $=$ alfalfa haylage/corn silage diet containing 27.4\% EGG offered for ad libitum intake; LF = EGG0 diet offered at $85 \%$ of DMI for EGG0.

${ }^{2}$ Contrasts: 1 = all ad libitum diets (EGG0, EGG9, EGG18, and EGG27) versus LF; 2 = EGG0 versus all diets containing EGG (EGG9, EGG18, and EGG27); 3 = linear effect of serial addition of EGG; and 4 = quadratic effect of serial addition of EGG.

all basal diets (Table 4). For TMR diets, fraction A was greater for the LF diet compared with all diets offered for ad libitum intake (48.6 vs. $43.4 \% ; P<0.001$ ), and EGG0 was greater than diets containing EGG (46.4 vs. 42.3\%; $P=0.001)$. Furthermore, fraction A declined linearly $(P<0.001)$ as a function of the inclusion rate of EGG within the diet, but the quadratic effect did not approach significance $(P=0.719)$. Fraction $\mathrm{B}$ for ad libitum diets considered collectively was greater than observed for the LF diet (37.4 vs. $32.5 \%$; $P<$ 0.001 ), and the positive relationship between fraction $\mathrm{B}$ and the proportion of EGG in the diet was explained by a linear $(P=0.002)$, but not quadratic $(P=0.497)$ effect. Fraction $\mathrm{C}$ was affected strongly by adding EGG to the TMR, which largely occurred because fraction $\mathrm{C}$ for EGG alone comprised $32.6 \%$ of DM, and was almost twice that of other dietary components. As a result, diets containing EGG exhibited a ruminally unavailable fraction that was greater than observed for EGG0 (20.1 vs. $17.2 \% ; P=0.002)$, and this response was explained by as a linear $(P=0.001)$ effect of EGG substitution rate within the diet. Discrete lag time for the 5 diets yielded no significant contrast $(P \geq 0.161)$. Ruminal $\mathrm{K}_{\mathrm{d}}$ for DM was $31.8 \%$ more rapid for the LF diet than for all other diets ( 0.058 vs. $0.044 / \mathrm{h} ; P=0.002)$. Inclusion of a perennial warm-season grass within diets had a predictable effect on $\mathrm{K}_{\mathrm{d}}$, slowing ruminal disappearance from $0.049 / \mathrm{h}$ for EGG0 to $0.038 / \mathrm{h}$ for EGG27. This response was explained by a linear $(P=0.045)$ effect with no quadratic $(P=0.977)$ character. Effective ruminal degradability of DM ranged from 58.7 to $67.8 \%$ across the 5 diets, with responses to contrast analysis that generally were similar to those described for fraction $\mathrm{A}$ and $\mathrm{K}_{\mathrm{d}}$.

As observed for DM disappearance characteristics of individual dietary components, NDF disappearance for alfalfa haylage, corn silage, and EGG varied little with the basal diet, and are condensed and reported as means averaged across all basal diets (Table 5). Unlike disappearance characteristics of DM, no significant $(P$ $\geq 0.059)$ contrasts were identified for any characteristic of ruminal NDF disappearance. However, 2 tendencies are worthy of note: both $\mathrm{K}_{\mathrm{d}}(P=0.097)$ and effective ruminal degradability of $\mathrm{NDF}(P=0.076)$ declined linearly with EGG substitution in the diet.

\section{Ruminal Fermentation}

Ruminal $\boldsymbol{p H}$. Polynomial regressions of ruminal $\mathrm{pH}$ on time expressed as hours from $0800 \mathrm{~h}$ were best fitted by a quartic model, where the quadratic term was 
Table 4. Ruminal in situ disappearance kinetics of DM for blended diets, as well as component silages comprising those diets ${ }^{1}$

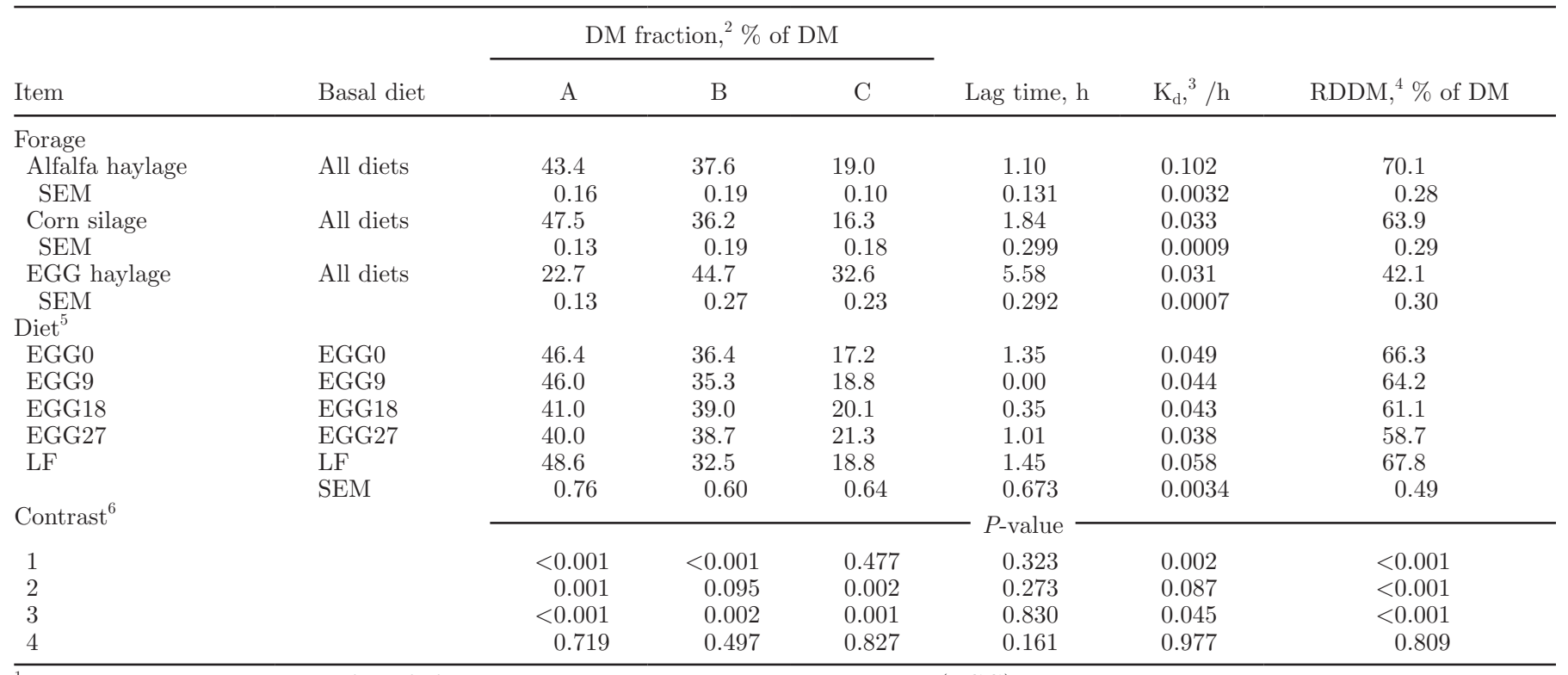

${ }^{1}$ Disappearance characteristics for alfalfa haylage, corn silage, and eastern gamagrass (EGG) haylage varied little with the basal diet, and only means averaged over all basal diets are presented.

${ }^{2} \mathrm{~A}=$ fraction disappearing too fast to measure; $\mathrm{B}=$ fraction disappearing at a measurable rate; $\mathrm{C}=$ fraction unavailable in the rumen.

${ }^{3}$ Ruminal disappearance rate of fraction B.

${ }^{4}$ Effective ruminal degradability of DM, calculated as $A+\left\{B \times\left[K_{d} /\left(K_{d}+K_{p}\right)\right]\right\}$, where $K_{p}=0.040 / h$, and represents the particulate passage rate.

${ }^{5}$ EGG0 = alfalfa haylage/corn silage diet containing no EGG offered for ad libitum intake; EGG9 = alfalfa haylage/corn silage diet containing 9.1\% EGG offered for ad libitum intake; EGG18 = alfalfa haylage/corn silage diet containing 18.3\% EGG offered for ad libitum intake; EGG27 = alfalfa haylage/corn silage diet containing 27.4\% EGG offered for ad libitum intake; LF = EGG0 diet offered at $85 \%$ of intake for EGG0.

${ }^{6}$ Contrasts: 1 = all ad libitum diets (EGG0, EGG9, EGG18, and EGG27) versus LF; 2 = EGG0 versus all diets containing EGG (EGG9, EGG18, and EGG27); 3 = linear effect of serial addition of EGG; and 4 = quadratic effect of serial addition of EGG.

dropped to improve fit. Using this regression approach, all regression coefficients for all dietary treatments were significant $(P \leq 0.041)$, except for the quartic coefficient for the EGG18 diet, which exhibited only a tendency $(P=0.082)$. However, to maintain consistency with respect to interpretation, this tendency was ignored and all diets were fitted to the identical customized quartic model. Coefficients of determination ranged from 0.951 to 0.997 across the 5 dietary treatments, indicating the regression model was very effective at describing diurnal changes in ruminal $\mathrm{pH}$. Based on these regression relationships, the $\mathrm{pH}$ minima observed for the EGG0, EGG9, EGG18, EGG27, and LF dietary treatments were $5.89,6.13,6.20,6.16$, and 5.76 , respectively. Because $\mathrm{pH}$ nadir determined on this basis were similar across all diets containing EGG, responses for the EGG9, EGG18, and EGG27 diets were merged to improve the clarity of presentation (Figure 1). Furthermore, inclusion of EGG in the diet delayed the timing of the $\mathrm{pH}$ minima modestly; $\mathrm{pH}$ minima occurred daily at 1727, 1736, and 1809 h, for LF, EGG0, and all diets containing EGG, respectively.
Ruminal VFA. Analysis of logical contrasts did not detect differences among diets for total production of ruminal VFA (overall mean $=100 \mathrm{~m} M ; P \geq 0.101$; Table 6); however, a numeric tendency $(P=0.101)$ was observed for total VFA production to decrease linearly with inclusion rate of EGG in the diet. The molar percentage of total VFA production composed of acetate was greater for heifers consuming diets containing EGG compared with EGG0 (82.3 vs. 80.4\%; $P$ $=0.034)$, and this percentage increased linearly $(P=$ 0.006 ) with inclusion rate for EGG. Molar percentages of propionate were static across dietary treatments, and no significant contrasts were detected (overall mean $=$ $22.8 \% ; P \geq 0.064)$. Similar responses were observed for the acetate:propionate ratio (overall mean $=3.67 ; P \geq$ $0.132)$. Heifers offered the LF diet exhibited a greater $(P=0.004)$ molar percentage of butyrate than heifers consuming diets for ad libitum intake. Similarly, heifers offered the EGG0 diet produced greater molar percentages of butyrate than heifers offered EGG (16.7 vs. $14.7 \% ; P<0.001)$, and these percentages declined $(P<0.001)$ with inclusion rate for EGG within the 
Table 5. Ruminal in situ disappearance kinetics of NDF for blended diets, as well as component silages comprising those diets ${ }^{1}$

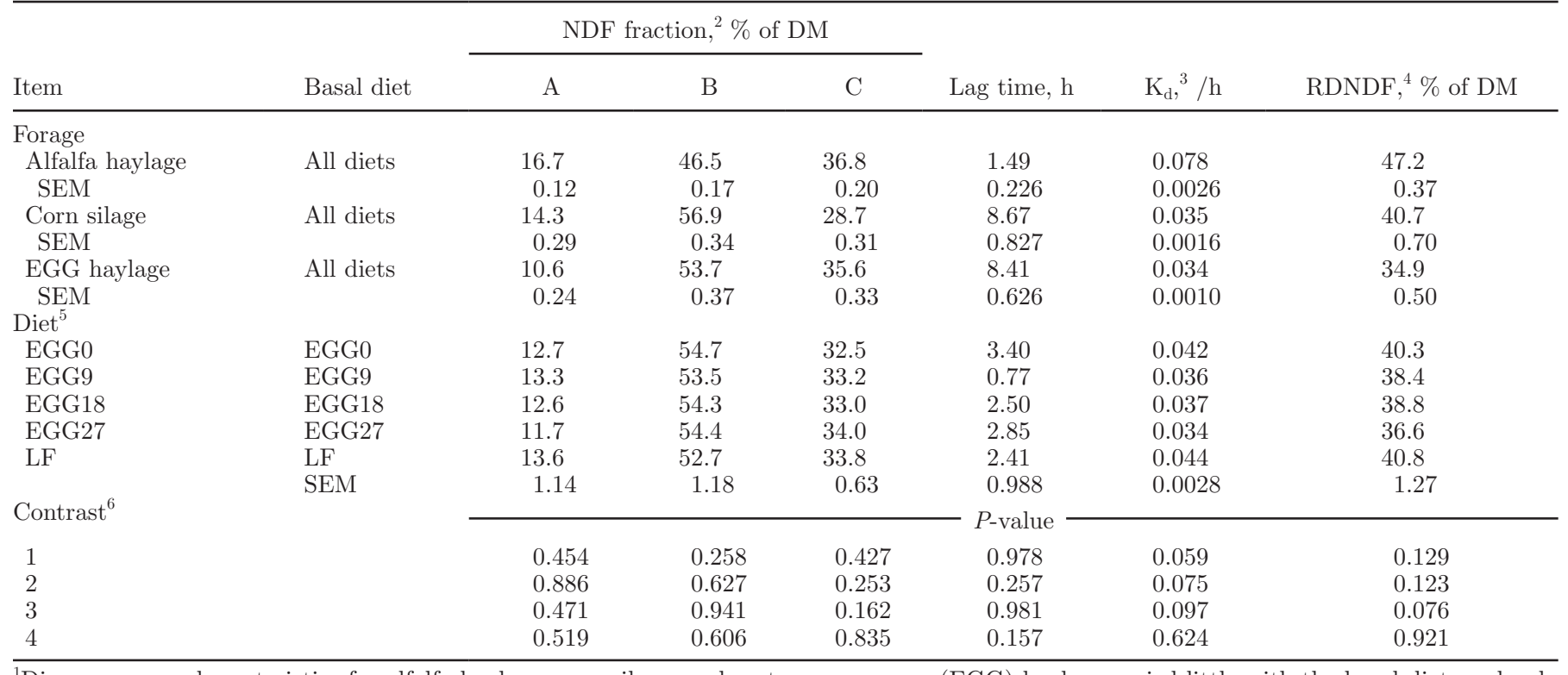

${ }^{1}$ Disappearance characteristics for alfalfa haylage, corn silage, and eastern gamagrass (EGG) haylage varied little with the basal diet, and only means averaged over all basal diets are presented.

${ }^{2} \mathrm{~A}=$ fraction disappearing too fast to measure; $\mathrm{B}=$ fraction disappearing at a measurable rate; $\mathrm{C}=$ fraction unavailable in the rumen.

${ }^{3}$ Ruminal disappearance rate of fraction B.

${ }^{4}$ Effective ruminal degradability of DM, calculated as $A+\left\{B \times\left[K_{d} /\left(K_{d}+K_{p}\right)\right]\right\}$, where $K_{p}=0.040 / h$, and represents the particulate passage rate.

${ }^{5} \mathrm{EGG0}=$ alfalfa haylage/corn silage diet containing no EGG offered for ad libitum intake; EGG9 = alfalfa haylage/corn silage diet containing 9.1\% EGG offered for ad libitum intake; EGG18 = alfalfa haylage/corn silage diet containing 18.3\% EGG offered for ad libitum intake; EGG27 = alfalfa haylage/corn silage diet containing 27.4\% EGG offered for ad libitum intake; LF = EGG0 diet offered at $85 \%$ of DMI for EGG0.

${ }^{6}$ Contrasts: 1 = all ad libitum diets (EGG0, EGG9, EGG18, and EGG27) versus LF; 2 = EGG0 versus all diets containing EGG (EGG9, EGG18, and EGG27); 3 = linear effect of serial addition of EGG; and 4 = quadratic effect of serial addition of EGG.

diet. All other VFA comprised only minor percentages of the total ruminal VFA production $(\leq 1.9 \%)$.

\section{DISCUSSION}

\section{Unique Characteristics of EGG Haylage}

With this unique application for EGG, the normal trade-off between forage yield and nutritive value is not a relevant forage-management consideration. To dilute the energy density of dairy heifer diets and potentially reduce voluntary DMI by increasing concentrations of structural fiber in the diet, it is important to maximize both the DM and NDF yield of EGG. Generally, the nutritive characteristics of EGG were consistent with those expected for a perennial warm-season grass, which include reduced concentrations of cell solubles and greater concentrations of NDF, relative to temperate grasses (Van Soest, 1982). In addition, estimates of $\mathrm{K}_{\mathrm{d}}$ for DM and NDF for EGG typically are slow, ranging generally from 0.023 to $0.060 / \mathrm{h}$ across a wide range of maturities (Coblentz et al., 1998; Mashingo et al.,
2008), and these estimates appear to be relatively comparable across leaf- and stem-tissue types (Coblentz et al., 1998). Our mean estimates of $K_{d}$ for DM and NDF from EGG (0.031 and $0.034 / \mathrm{h}$, respectively) produced in a northern climate were consistent with these previous reports. Although not discussed previously, preliminary samples of EGG were taken from each wagon load of precision-chopped EGG before ensiling, thereby yielding a mean NDF concentration of (mean \pm SD) $76.9 \pm 0.64 \%$ across 7 loads. This concentration was reduced by 7.2 percentage units to $69.7 \%$ in the haylage, based on weekly samples obtained throughout the trial (Table 1), and may indicate some release of xylose and arabinose subunits from hemicellulose, either through the action of hemicellulases within the forage or via acid hydrolysis (Dewar et al., 1963). Regardless, the concentration of NDF was reduced by about $9 \%$ in the haylage, which was not desirable from the standpoint of reducing intake on the basis of gut fill.

On a practical basis, a potentially important observation related specifically to EGG was made during the trial. When EGG was included within the diets 
Table 6. Effects of diets with or without eastern gamagrass haylage (EGG) on production of ruminal VFA within Holstein replacement heifers ${ }^{1}$

\begin{tabular}{|c|c|c|c|c|c|c|c|c|c|c|}
\hline Item & \multicolumn{5}{|c|}{ Blended diet ${ }^{2}$} & SEM & \multicolumn{4}{|c|}{ Contrast, ${ }^{3} P$-value } \\
\hline Total VFA, mM & 106 & 103 & 101 & 97 & 95 & 3.8 & 0.113 & 0.224 & 0.101 & 0.854 \\
\hline Propionate, \% & 23.0 & 23.2 & 23.1 & 22.6 & 22.0 & 0.47 & 0.064 & 0.837 & 0.467 & 0.508 \\
\hline Butyrate, \% & 16.7 & 15.5 & 14.6 & 14.0 & 16.6 & 0.42 & 0.004 & $<0.001$ & $<0.001$ & 0.406 \\
\hline Isobutyrate, \% & 1.3 & 1.4 & 1.5 & 1.5 & 1.3 & 0.06 & 0.069 & 0.063 & 0.053 & 0.470 \\
\hline Acetate:propionate & 3.56 & 3.60 & 3.61 & 3.76 & 3.82 & 0.108 & 0.132 & 0.465 & 0.226 & 0.621 \\
\hline
\end{tabular}

${ }^{1}$ Data represent the mean of sampling times taken at 4-h intervals during 2 consecutive days.

${ }^{2}$ EGG0 = alfalfa haylage/corn silage diet containing no EGG offered for ad libitum intake; EGG9 = alfalfa haylage/corn silage diet containing 9.1\% EGG offered for ad libitum intake; EGG18 = alfalfa haylage/corn silage diet containing 18.3\% EGG offered for ad libitum intake; EGG27 = alfalfa haylage/corn silage diet containing 27.4\% EGG offered for ad libitum intake; LF = EGG0 diet offered at $85 \%$ of intake for EGG0.

${ }^{3}$ Contrasts: 1 = all ad libitum diets (EGG0, EGG9, EGG18, and EGG27) versus LF; 2 = EGG0 versus all diets containing EGG (EGG9, EGG18, and EGG27); 3 = linear effect of serial addition of EGG; and 4 = quadratic effect of serial addition of EGG.

${ }^{4}$ Percentage of total ruminal VFA production.

developed for this trial, no visual evidence was found of undesirable sorting behaviors by heifers, which have been reported commonly when chopped straw is included within the diet (Greter et al., 2008). It is possible that the absence of undesirable sorting behaviors by these heifers can be associated with the general homogeneity of silage crops, particularly within blended diets, compared with diets that contain dry chopped hay or straw. However, EGG often is described as being very palatable to livestock. It remains unclear whether

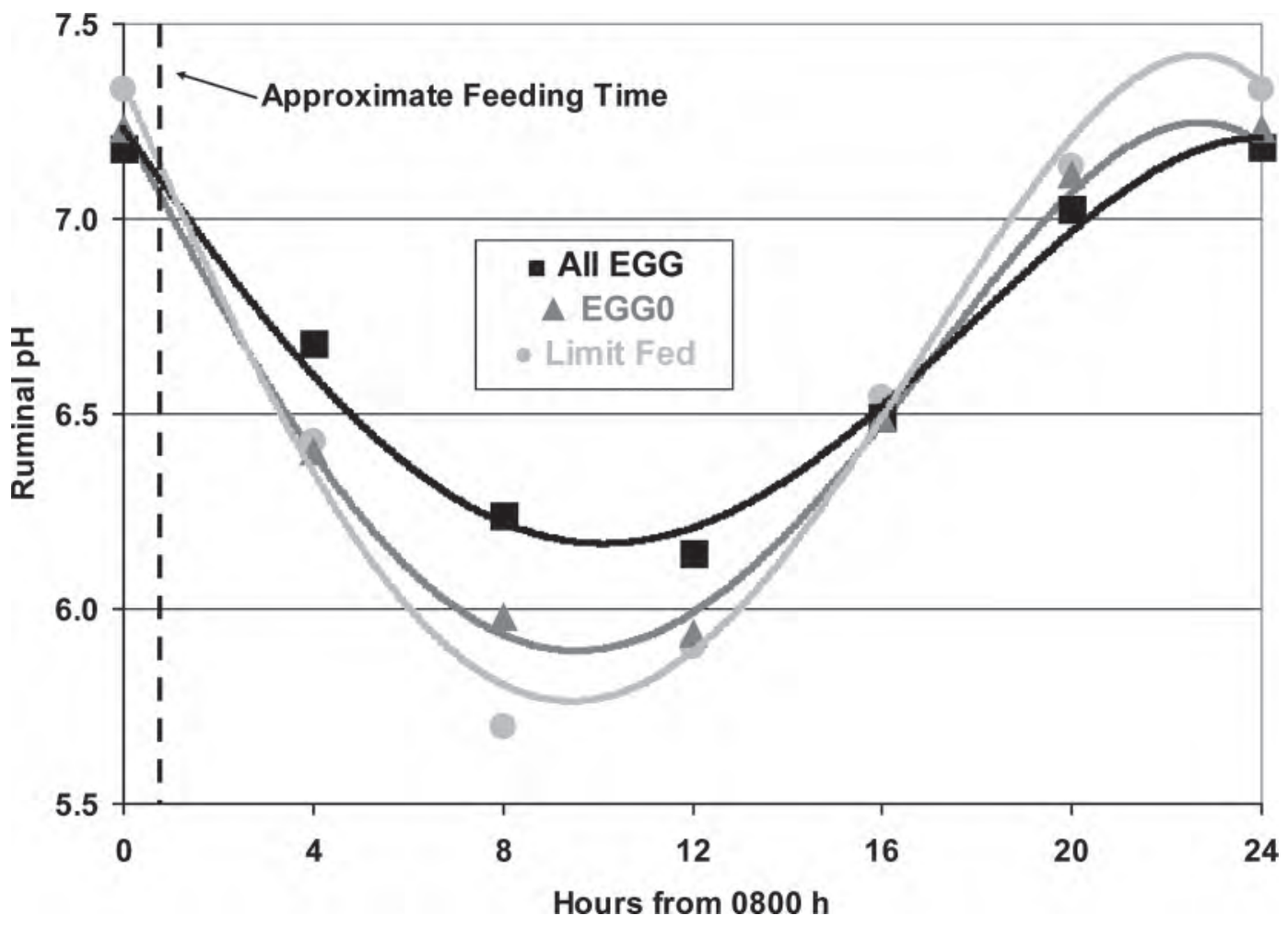

Figure 1. Regression lines depicting ruminal pH responses over a 24-h diurnal cycle for heifers consuming (1) a diet comprising a 47:53 blend of alfalfa haylage and corn silage (EGG0; $\left.\mathrm{Y}=-0.000039 \mathrm{x}^{4}+0.0013 \mathrm{x}^{3}-0.23 \mathrm{x}+7.24 ; \mathrm{R}^{2}=0.997\right)$; (2) the EGG0 diet limit-fed (LF) at $85 \%$ of the voluntary DMI of EGG0 ( $\left.\mathrm{Y}=-0.000047 \mathrm{x}^{4}+0.0016 \mathrm{x}^{3}-0.27 \mathrm{x}+7.40 ; \mathrm{R}^{2}=0.991\right)$; or (3) diets containing $9.1,18.3$, or $27.4 \%$ eastern gamagrass haylage (EGG). Ruminal $\mathrm{pH}$ reached similar minima for the 3 diets containing EGG; for clarity of presentation, regression was conducted on the mean response (All EGG) for these diets $\left(Y=-0.000025 \mathrm{x}^{4}+0.00089 \mathrm{x}^{3}-0.17 \mathrm{x}+7.23 ; \mathrm{R}^{2}=0.927\right)$. 
this palatability is a function of limited numbers of reproductive tillers, a high proportion of leaf to stem tissue (Coblentz et al., 1998), or other sensory factors, including a distinct odor that is especially noticeable under forced-air drying. The visual observation that diets containing EGG were not sorted by heifers may allow for greater flexibility with respect to bunk space because less desirable feed particles would not be discriminated against, and subordinate heifers would have access to the same diet as aggressive heifers, whenever they are able to reach the feed bunk. It is well understood that competition among heifers for bunk space alters feeding patterns, reduces access to feed, and increases day-to-day variation in feeding behavior (DeVries and von Keyserlingk, 2009), as well as withinpen variability with respect to ADG (Longenbach et al., 1999). The use of EGG to create a nonsortable diet has the potential to alleviate many management problems associated with inclusion of chopped straw and warrants further investigation.

\section{Dietary Effects on NDF Concentrations, Energy Density, and Voluntary Intake}

Conceptually, the caloric intake of dairy heifers can be limited by (1) reducing the energy density of the diet, (2) reducing the intake of the diet, or (3) through both mechanisms simultaneously. Serial addition of 9.1, 18.3 , or $27.4 \%$ EGG, primarily as a substitute for corn silage, was effective in reducing calculated estimates of TDN by $4.3,7.3$, or $10.1 \%$, respectively. Greater respective reductions were observed for $\mathrm{NE}_{\mathrm{G}}$, which were 9.3, 15.9, and 22.4\% less than observed for EGG0 (Table 1). In part, this was facilitated by substituting low-starch (2.2\%) EGG haylage for corn silage that contained $35.2 \%$ starch (Table 1). These estimates were based on the summative approach (NRC, 2001), in which the 48-h NDFD option was used to estimate truly digestible fiber. As noted previously, a serious bias has been noted between the lignin and 48-h NDFD options for estimating truly digestible fiber within EGG forages grown in central Wisconsin (Coblentz et al., 2010a). Obviously, this uncertainty complicated initial diet formulation, and it has been attributed to the relatively limited lignification of highly fibrous forage that was likely a consequence of the cool growing conditions existing throughout central Wisconsin relative to more southerly latitudes (Coblentz et al., 2010a).

An application of the gut-fill theory of intake regulation was described recently by Hoffman et al. (2008); in that work, intakes by dairy heifers offered mixed forage-based diets containing between 36.1 and $49.2 \%$ NDF were explained by exponential models that relied on dietary NDF to adjust DMI. Using the NDF con- centrations for the EGG0, EGG9, EGG18, and EGG27 diets (Table 1), and assuming these diets were offered to a 400-kg Holstein heifer, which was the approximate mean BW for the 105-d trial, the projected DMI of these diets would be $9.41,9.13,8.92$, and $8.66 \mathrm{~kg} / \mathrm{d}$, respectively. This projection of intake restriction, based partially on the NDF concentration of the diet, was corroborated experimentally in our trial, where the actual DMI of the EGG0 diet was closely matched to the model projection $(9.40 \mathrm{~kg} / \mathrm{d})$ and DMI decreased with the proportion of EGG in the diet, yielding significant linear $(P<0.001)$ and quadratic $(P=0.005)$ effects of EGG substitution rate. However, from a practical standpoint, actual DMI across all diets containing EGG were essentially identical within this experiment (Table 2 ). Conversely, intakes of NDF for these diets increased linearly $(P<0.001)$ from 3.72 to $4.35 \mathrm{~kg}$ of NDF/d, respectively, which was consistent with the approximate $1.0 \%$ of BW practical limit for heifers documented by Hoffman et al. (2008). Generally, these results also support the findings of Greter et al. (2008), who found that DMI of blended diets for heifers decreased linearly by including 10 or $20 \%$ straw within the diet. However, this was accomplished with EGG in our study, and without the undesirable sorting behaviors that specifically exhibit prejudice against long particles of straw (Greter et al., 2008).

Based on our results, EGG was used effectively to limit caloric intakes by dairy heifers (Table 2) and this was accomplished by diluting both the energy density of the diet, as well as restricting DMI on the basis of gut fill by increasing dietary NDF. This response represented a $15 \%$ reduction in TDN intake for the EGG27 diet (5.48 $\mathrm{kg}$ of TDN/d) compared with the EGG0 diet $(6.41 \mathrm{~kg}$ of TDN/d). Similar trends were observed for other estimates of energy intake $\left(\mathrm{ME}, \mathrm{NE}_{\mathrm{G}}\right.$, and $\left.\mathrm{NE}_{\mathrm{M}}\right)$, with the relationship between energy intakes and the proportion of EGG in the diet explained by both linear $(P<0.001)$ and quadratic $(P \leq 0.006)$ effects of EGG inclusion rate in all cases. The practical management benefit of reducing energy intakes was the resultant linear $(P<0.001$; Table 3$)$ reduction of ADG; this response had no quadratic $(P=0.403)$ character and amounted to about $0.01 \mathrm{~kg} / \mathrm{d}$ for each percentage unit of EGG in the diet. As such, it was necessary for EGG to comprise about $30 \%$ of the diet to reduce ADG to comparable levels with LF heifers, and within reasonable proximity to typical ADG targets for heifers of this size (Hoffman, 1997).

\section{Dietary Effects on Ruminal Fermentation}

Several recent studies have reported relatively little effect of limit feeding on ruminal $\mathrm{pH}$ (Zanton and Hein- 
richs, 2008; Kruse et al., 2010). Specifically, Kruse et al. (2010) offered an ad libitum diet to gravid heifers formulated at $56.5 \%$ TDN, as well as 2 limit-fed diets formulated at $65.0 \%$ TDN, one of which included an ionophore. In that study, neither the main effect of diet nor the interaction of diet with time postfeeding affected ruminal $\mathrm{pH}$. The regression approach used to evaluate $\mathrm{pH}$ responses in the present study (Figure 1) suggests that diets that contained no EGG were subject to a more extensive $\mathrm{pH}$ depression than diets containing EGG. Relative to diets containing EGG (minimum pH $=6.17$ ), the minimum $\mathrm{pH}$ for EGG0 was an additional $0.28 \mathrm{pH}$ units more acidic, and the differential between EGG diets and LF was even greater (0.41 pH units). It remains unclear whether this response was caused by differences in (1) the relative amounts of starch in these diets, (2) the flow of salivary buffers resulting from the additional chewing activity required by adding a highly fibrous warm-season grass to the blended diet, (3) the respective consumption rates of the diets, or (4) a combination of these or other factors. Regardless, little evidence existed of additional buffering of ruminal $\mathrm{pH}$ associated with increasing the percentage of EGG in the diet beyond $9.1 \%$ of DM. Perhaps most importantly, the minimum ruminal $\mathrm{pH}$ associated with these diets bridges a range in which fiber digestion can be impaired. Hoover (1986) thoroughly reviewed factors affecting fiber digestion and concluded that a moderate depression of ruminal $\mathrm{pH}$ to about 6.0 may have a minor effect on fiber digestion, but increasingly acidic conditions may depress numbers of fibrolytic microbes and severely depress fiber digestion. Although the mean $\mathrm{pH}$ minima for LF and EGG0 diets were $\geq 5.76$ (Figure 1), specific measurements for individual animal replicates taken at $2000 \mathrm{~h}$ were as acidic as 5.05 and 5.67 , respectively, and easily fell within the range with potential to suppress digestion of NDF.

\section{Dietary Effects on In Situ Disappearance Kinetics}

Ruminal in situ disappearance kinetics of DM and NDF for individual dietary components varied little with the basal diet (Tables 4 and 5, respectively); therefore, differences in kinetic characteristics for the blended diets primarily can be explained on the basis of relative percentages of EGG and corn silage within the diet. Eastern gamagrass haylage ensiled intentionally from a single, delayed harvest in early September with the specific goal of minimizing the caloric density of the harvested forage exhibited an immediately available fraction that comprised only $22.7 \%$ of the total DM. This was approximately half the percentage observed for both alfalfa haylage (43.4\%) and corn silage (47.5\%), and is consistent with the limited concentrations of cell solubles frequently found within perennial warm-season grasses relative to temperate forages (Van Soest, 1982). Conversely, and largely as a result of the delayed, earlySeptember harvest, fraction C for EGG (32.6\%) was twice that observed for corn silage (16.3\%), and almost twice that observed for alfalfa haylage (19.0\%). As a result, negative $(P<0.001)$ and positive $(P=0.001)$ linear effects of EGG inclusion rate were observed for fractions A and C, respectively. Furthermore, perennial warm-season grasses typically exhibit very slow estimates of ruminal $\mathrm{K}_{\mathrm{d}}$ for DM that often range between 0.020 and $0.060 / \mathrm{h}$ (Coblentz et al., 1998; Ogden et al., 2005; Mashingo et al., 2008); these characteristics were observed for in situ analysis of blended diets, which declined linearly from 0.049 to $0.038 / \mathrm{h}$ with inclusion of EGG within the diet. As a result of these combined effects, the inclusion of EGG also reduced the effective ruminal DM disappearance of blended diets linearly $(P$ $<0.001$ ) from 66.3 to $58.7 \%$, which represents a reduction of about $11.5 \%$.

Unlike ruminal disappearance of DM, fractions A, $\mathrm{B}$, and $\mathrm{C}$ for $\mathrm{NDF}$ disappearance did not vary $(P \geq$ 0.162 ; Table 5) across blended diets, in part because the partitioning of NDF was not affected by the large differences in immediate DM loss via solubility or other mechanisms that were observed for alfalfa haylage and corn silage compared with EGG (Table 4). Although no differences existed among blended diets with respect to partitioning of NDF on the basis of susceptibility to ruminal degradation, tendencies were observed for linear declines for both $\mathrm{K}_{\mathrm{d}}(P=0.097)$ and effective ruminal degradability $(P=0.076)$ as more EGG was included in the diet; however, these represented relatively small overall ranges $(0.042$ to $0.034 / \mathrm{h}$ and 40.3 to $36.6 \%$ of NDF, respectively) and may be of limited practical relevance. Generally, in situ analysis of NDF degradation did not suggest that NDF digestion was affected negatively by $\mathrm{pH}$ minima for the EGG0 (pH $=5.89)$ and $\mathrm{LF}(\mathrm{pH}=5.76)$ diets (Figure 1$)$ that fell below the threshold of $\mathrm{pH}=6$ at which fiber digestion may be impaired (Hoover, 1986).

\section{CONCLUSIONS}

Based on our results, EGG was effective in limiting caloric intakes by dairy heifers, and this was accomplished by diluting both the energy density of the diet, as well as restricting DMI on the basis of gut fill by increasing dietary NDF. The practical benefit of reducing energy intakes was a subsequent linear reduction of ADG, which had no quadratic character, and amounted to about $0.01 \mathrm{~kg} / \mathrm{d}$ for each percentage unit of EGG in the diet. As such, it was necessary to substitute EGG primarily for corn silage until it comprised about $30 \%$ 
of the diet to reduce ADG to comparable levels with LF heifers, which was within reasonable proximity to typical ADG targets for heifers of this size. When EGG was included within the alfalfa haylage/corn silage diets developed for this trial, no visual evidence existed of undesirable sorting behaviors by heifers, which are common when chopped straw is included in the diet. This is important because a functionally nonsortable diet potentially may allow for greater flexibility with respect to bunk space because less desirable feed particles are not discriminated against, and subordinate heifers have access to the same diet as aggressive heifers whenever they are able to reach the feed bunk. This characteristic of EGG was suspected, but not completely understood or verified during the pretrial design phase of the experiment, but it warrants future investigation because of obvious relevant application to commercial dairy heifer management. In light of these results, other perennial warm-season grasses, such as switchgrass (Panicum virgatum L.), may work similarly within this management context; however, the acceptability of their use likely would be dependent on demonstration of suitable silage fermentation characteristics.

\section{REFERENCES}

AOAC (Association of Official Analytical Chemists). 1990. Official Methods of Analysis. 15th ed. AOAC, Arlington, VA.

AOAC International. 1998. Official Methods of Analysis. 16th ed. AOAC International, Arlington, VA.

Bates, L. S., M. Bender, and W. Jackson. 1981. Eastern gamagrass. Seed structure and protein quality. Cereal Chem. 58:138-141.

Brejda, J. J., J. R. Brown, J. M. Asplund, T. E. Lorenz, J. L. Reid, and J. Henry. 1994. Eastern gamagrass silage fermentation characteristics and quality under different nitrogen rates. J. Prod. Agric. 7:477-482.

Brejda, J. J., J. R. Brown, T. E. Lorenz, J. Henry, and S. R. Lowry. 1997. Variation in eastern gamagrass forage yield with environments, harvests, and nitrogen rates. Agron. J. 89:702-706.

Brejda, J. J., J. R. Brown, T. E. Lorenz, J. Henry, J. L. Reid, and S. R. Lowry. 1996. Eastern gamagrass responses to different harvest intervals and nitrogen rates in northern Missouri. J. Prod. Agric. 9:130-135.

Coblentz, W. K., K. P. Coffey, and J. E. Turner. 1999. Review: Quality characteristics of eastern gamagrass forages. Prof. Anim. Sci. 15:211-223.

Coblentz, W. K., J. O. Fritz, R. C. Cochran, W. L. Rooney, and K. K. Bolsen. 1997. Protein degradation responses to spontaneous heating in alfalfa hay evaluated by in situ and ficin methods. J. Dairy Sci. 80:700-713.

Coblentz, W. K., J. O. Fritz, W. H. Fick, R. C. Cochran, and J. E. Shirley. 1998. In situ dry matter, nitrogen, and fiber degradation of alfalfa, red clover, and eastern gamagrass at four maturities. J. Dairy Sci. 81:150-161.

Coblentz, W. K., and P. C. Hoffman. 2009. Effects of spontaneous heating on fiber composition, fiber digestibility, and in situ disappearance kinetics of NDF for alfalfa-orchardgrass hays. J. Dairy Sci. 92:2875-2895.

Coblentz, W. K., P. C. Hoffman, W. E. Jokela, and M. G. Bertram. 2010a. Unique dairy applications for eastern gamagrass in central Wisconsin: II. Nutritive value and energy density. Agron. J. 102:1720-1730.
Coblentz, W. K., W. E. Jokela, P. C. Hoffman, and M. G. Bertram. 2010b. Unique dairy applications for eastern gamagrass in central Wisconsin: I. Yield potential. Agron. J. 102:1710-1719.

DeVries, T. J., and M. A. G. von Keyserlingk. 2009. Competition for feed affects the feeding behavior of growing dairy heifers. J. Dairy Sci. 92:3922-3929.

Dewar, W. A., P. McDonald, and R. Whittenbury. 1963. The hydrolysis of grass hemicelluloses during ensilage. J. Sci. Food Agric. 14:411-417.

Esser, N. M., P. C. Hoffman, W. K. Coblentz, M. W. Orth, and K. A. Weigel. 2009. The effect of dietary phosphorus on bone development in dairy heifers. J. Dairy Sci. 92:1741-1749.

Eun, J. S., V. Fellner, J. C. Burns, and M. L. Gumpertz. 2003. Eastern gamagrass evaluated as hay or silage for lactating dairy cows. Prof. Anim. Sci. 19:362-369.

Goering, H. K., and P. J. Van Soest. 1970. Forage Fiber Analyses (Apparatus, Reagents, Procedures, and Some Applications). Agric. Handbook No. 379. Pages 8-11. US Department of AgricultureAgricultural Research Service (USDA-ARS), Washington, DC.

Greter, A. M., T. J. DeVries, and M. A. G. von Keyserlingk. 2008. Nutrient intake and feeding behavior of growing dairy heifers: Effects of dietary dilution. J. Dairy Sci. 91:2786-2795.

Hoffman, P. C. 1997. Optimum body size of Holstein replacement heifers. J. Anim. Sci. 75:836-845.

Hoffman, P. C., N. M. Brehm, S. G. Price, and A. Prill-Adams. 1996. Effect of accelerated postpubertal growth and early calving on lactation performance of primiparous Holstein heifers. J. Dairy Sci. 79:2024-2031.

Hoffman, P. C., C. R. Simson, and M. Wattiaux. 2007. Limit feeding of gravid Holstein heifers: Effect on growth, manure nutrient excretion, and subsequent early lactation performance. J. Dairy Sci. 90:946-954.

Hoffman, P. C., K. A. Weigel, and R. M. Wernberg. 2008. Evaluation of equations to predict dry matter intake of dairy heifers. J. Dairy Sci. 91:3699-3709.

Hoover, W. H. 1986. Chemical factors involved in ruminal fiber digestion. J. Dairy Sci. 69:2755-2766.

Kruse, K. A., D. K. Combs, N. M. Esser, W. K. Coblentz, and P. C. Hoffman. 2010. Evaluation of potential carryover effects associated with limit feeding gravid Holstein heifers. J. Dairy Sci. 93:5374-5384.

Lammers, B. P., A. J. Heinrichs, and R. S. Kensinger. 1999. The effects of accelerated growth rates and estrogen implants in prepubertal Holstein heifers on estimates of mammary development. J. Dairy Sci. 82:1753-1764.

Longenbach, J. I., A. J. Heinrichs, and R. E. Graves. 1999. Feed bunk length requirements for Holstein dairy heifers. J. Dairy Sci. 82:99-109

Mashingo, M. S. H., D. W. Kellogg, W. K. Coblentz, and K. S. Anschutz. 2008. Effect of harvest dates on yield and nutritive value of eastern gamagrass. Prof. Anim. Sci. 24:363-373.

Mertens, D. R. 1992. Critical conditions in determining detergent fibers. Page C-1 in Proc. Natl. Forage Testing Assoc. Forage Anal. Workshop, Denver, CO. Natl. Forage Testing Assoc., Omaha, NE.

Mertens, D. R., and J. R. Loften. 1980. The effect of starch on forage fiber digestion kinetics in vitro. J. Dairy Sci. 63:1437-1446.

NRC. 2001. Nutrient Requirements of Dairy Cattle. 7th rev. ed. National Academy Press, Washington, DC.

Ogden, R. K., W. K. Coblentz, K. P. Coffey, J. E. Turner, D. A. Scarbrough, J. A. Jennings, and M. D. Richardson. 2005. Ruminal in situ disappearance kinetics of dry matter and fiber in growing steers for common crabgrass sampled on seven dates in northern Arkansas. J. Anim. Sci. 83:1142-1152.

Ørskov, E. R., and I. McDonald. 1979. The estimation of protein degradability in the rumen from incubation measurements weighted according to rate of passage. J. Agric. Sci. 92:499-503.

Radcliff, R. P., M. J. Vandehaar, L. T. Chapin, T. E. Pilbeam, D. K. Beede, E. P. Stanisiewski, and H. A. Tucker. 2000. Effects of diet and injection of bovine somatotropin on prepubertal growth and first-lactation milk yields of Holstein cows. J. Dairy Sci. 83:23-29. 
SAS Institute. 2002. SAS User's Guide: Statistics. Version 9.2. SAS Inst. Inc., Cary, NC.

Schulte, E. E., J. B. Peters, and P. R. Hodgson. 1987. Wisconsin procedures for soil testing, plant analysis and feed and forage analysis. Dept. Soil Sci. Bull. No. 6. University of Wisconsin, Madison.

Sejrsen, K., J. T. Huber, H. A. Tucker, and R. M. Akers. 1982. Influence of nutrition on mammary development in pre- and postpubertal heifers. J. Dairy Sci. 65:793-800.

St-Pierre, N. R. 2007. Design and analysis of pen studies in the animal sciences. J. Dairy Sci. 90(Suppl. 1):E87-E89.

Stubbendieck, J., S. L. Hatch, and K. J. Kjar. 1982. North American Range Plants. 2nd ed. Univ. Nebraska Press, Lincoln.

Van Amburgh, M. E., D. M. Galton, D. E. Bauman, R. W. Everett, D. G. Fox, L. E. Chase, and H. N. Erb. 1998. Effects of three prepubertal body growth rates on performance of Holstein heifers during first lactation. J. Dairy Sci. 81:527-538.

Van Soest, P. J. 1982. Nutritional Ecology of the Ruminant. Cornell Univ. Press, Ithaca, NY.

Van Soest, P. J., J. B. Robertson, and B. A. Lewis. 1991. Methods for dietary fiber, neutral detergent fiber, and nonstarch polysaccharides in relation to animal nutrition. J. Dairy Sci. 74:3583-3597.
Vanzant, E. S., R. C. Cochran, and E. C. Titgemeyer. 1998. Standardization of in situ techniques for ruminant feedstuff evaluation. J. Anim. Sci. 76:2717-2729.

Vanzant, E. S., R. C. Cochran, E. C. Titgemeyer, S. D. Stafford, K. C. Olsen, D. E. Johnson, and G. St. Jean. 1996. In vivo and in situ measurements of forage protein degradation in cattle. J. Anim. Sci. 74:2773-2784.

Waller, S. S., and J. K. Lewis. 1979. Occurrence of $\mathrm{C}_{3}$ and $\mathrm{C}_{4}$ photosynthetic pathways in North American grasses. J. Range Manage. $32: 12-28$

Wildman, E. E., G. M. Jones, P. E. Wagner, R. L. Boman, H. F. Troutt Jr., and T. N. Lesch. 1982. A dairy cow body condition scoring system and its relationship to selected production characteristics. J. Dairy Sci. 65:495-501.

Zanton, G. I., and A. J. Heinrichs. 2007. The effects of controlled feeding of a high-forage or high-concentrate ration on heifer growth and first lactation milk production. J. Dairy Sci. 90:3388-3396.

Zanton, G. I., and A. J. Heinrichs. 2008. Rumen digestion and nutritional efficiency of dairy heifers limit-fed a high forage ration to four levels of dry matter intake. J. Dairy Sci. 91:3579-3588. 